\title{
Manufacturing Strategy and Improvement Activities of Sri Lankan Furniture Manufacturers
}

\author{
H.S.C. Perera
}

Abstract: Furniture industry is a significant industry in the manufacturing sector in Sri Lanka based on the number of employees. This paper studies the manufacturing strategy of Sri Lankan furniture industry. A questionnaire survey was carried out among the key players of the industry to investigate the manufacturing strategy and improvement activities. Cluster analysis is used to identify the strategic manufacturing groups based on their competitive priorities and three strategic groups were formed. Top competitive priorities of the Sri Lankan furniture manufacturers were identified as low price, conformance quality and product performance. Performance improvement activities under three major categories namely advanced manufacturing technologies, integrated information systems and advanced management systems were investigated. Manufacturing strategy stages of the furniture manufacturers were studied based on the Hayes and Wheelwright model and it is found out that majority of the companies have the characteristics of stage II of the model.

Keywords: Manufacturing Strategy, Improvement Activities, Furniture Industry

\section{Introduction}

The furniture Industry is a basic industry in most of the industrialized countries, representing in general betwcen 2 and $4 \%$ of the production value of the manufacturing sector [1]. It was the largest traditional, lowtech sector in the world during 1994-98 period exceeding the value of export trade in the apparel industry and the footwear industry [2]. Traditional furniture making countries take up over $70 \%$ of the global market. Meanwhile, developing countries and regions like China, Southeast Asia, Poland and Mexico, with China taking the lead, have built upon their respective competitive advantages and gradually have covered almost $30 \%$ of the world market. The furniture industry in such countries is developing strongly and showing great potentials. The European Union furniture industry accounts for about half of the world's furniture production. The production value of this industry in this region is around $€ 82$ billion. Considered to be a labor-intensive industry it provides employment for around 1 million people in Europe. Among the European countries, Germany takes the lead as the largest furniture producing country, accounting for about $27 \%$ of total EU production. This is followed by Italy $(21.6 \%)$, France $(13.5 \%)$ and the UK (10.4\%) [3].

With more than 50,000 furniture manufacturers employing 5 million workers, the Chinese furniture industry has increased exports by 335 percent from 1994 to 2001, replacing Italy as the world's largest furniture exporting country. China's furniture exports to the U.S. have grown at an average annual rate of more than 35 percent [4]. According to a recent estimate, the Indian furniture industry is estimated at around Rs. 350 billion. Eighty-five per cent of this falls into the unorganized sector. According to a study by the World Bank, the organized furniture industry is expected to grow by 20 per cent a year and India, Brazil and Russia will witness a boom [3].

Even though Sri Lankan furniture industry does not own a significant portion in the world market compare to the above giants, it is a significant industry in the manufacturing sector in Sri Lanka. Based on the number of employees it ranks to third place with 13.62 percent employees in the small industries and ranks fourth place with 4.70 percent employees in the medium and large industries [5]. According to the figures of Department of Census and Statistics, Sri Lanka, total value of output in wood and furniture industry is Rs. 1.719 billion with a value addition of Rs. 984 million in the year 2000 .

At present, Sri Lankan furniture industry is capable of catering not only to the domestic market but also to the overseas markets. Major

Eng. (Dr.) H.S.C. Perera, B.Sc.Eng. (Moraluwa), M.Eng. (AIT), D.Eng. (AIT), MIE (Sri Lanka), Senior Lechurer, Department of Management of Technology, Universily of Moratuwa. 
foreign markets areUK, USA, India, Maldives, Saudi Arabia, France and Germany.

The furniture manufactured in Sri Lanka includes houschold furniture (bedroom \& living room, kitchen furniture, garden furniture), office furniture (computer tables, office tables, etc.) commercial and institutional furniture (furniture for hotels and schools, hospitals, etc.) Furniture in knockdown form/built in furniture is also exported according to buyer specifications. Sri Lanka is competent in producing such items to the high end of the market.

Sri Lankan furniture industry is under increasing pressure due to globalization, changing customer choice and sophisticated markets. The market for the furniture is becoming increasingly international. Cheaper imports increase the competition in local market. The manufacturers have to meet several competitive priorities simultaneously. The new competitive priorities are in terms of reduced cost, higher quality, wider range of product, shorter delivery time and better service. Even though Sri Lankan furniture manufactures cater to the international market, most of the firms are still very far from world class manufacturing practices. With the high intensive global competition, it is imperative for Sri Lankan furniture manufacturers to boost their performance through strategically planned improvement programmes. Manufacturing managers should understand the strengths and weaknesses of the present practices of the industry. In this context, it is vital to study the strategic formation of Sri Lankan furniture manufacturers and improvement activities.

The research described here has following objectives:

- To identify the strategic groups of key players of Sri Lankan furniture industry.

- To identify the improvement activities of various strategic groups.

- To analyze the stages of manufacturing strategy.

This paper is organized as the follows: Section 2 deals with the literature on manufacturing strategy. Research methodology for survey is discussed in section 3 . Findings are presented in section 4 .

\section{Manufacturing Strategy}

Importance of the manufacturing strategy for competitiveness was first discussed by Skiner [6]. Since his landmark paper, a number of researchers have pointed out the manufacturing function as the missing link in corporate strategic process and emphasized that manufacturing can be a competitive weapon if managed properly $[8$, $9,10]$

Various researchers $[6,8,10]$ identified expectation on attributes such as cost, quality, delivery dependability, delivery speed, flexibility and innovation which are popularly termed as competitive priorities or manufacturing performance objectives. Noori and Radford [11] introduced service as another dimension to competitive priorities. Skinner [6] indicated that performance objectives could not be achieved simultaneously and there should be trade-offs between them. The interaction between objectives in the form of trade-offs has, however, become a debatable issue. In 1969 Skinner believed that it is impossible for manufacturing companies to make a wide range of high quality and low cost products quickly[6]. Wheelwright [12] challenged this assumption, having noted that many Japanese managers scek to improve quality and reduce costs simultaneously. De Meyer et al. [13] pointed out that Japanese managers overcome trade-offs by attacking quality, time, cost and flexibility sequentially. Slack [14] included the time dimension into the debate and argued that while no manufacturer can double its product range tomorrow without increasing cost. This may well be possible over a longer period. This connects with the continuous improvement philosophy [15].

Researchers on manufacturing strategy have identified set of companies following similar or generic manufacturing strategies. Following are some important studies.

- Based on 100 case studies Stobaugh and Telesio [16] identified three groups of international manufacturing strategy - cost based, technology based and market driven.

- Miller and Roth [9] examined the strategic management practices of 188 North American companies and identified three groups of generic manufacturing strategy caretakers, marketers and innovators.

- De Meyer [13] used results from the European Manufacturing Futures survey to 
identify three groups - high performance product manufactures, manufacturing innovators and marketing oriented manufacturers.

- Sweeney and Szwejczewski [17] analyzed UK Best Factory Award database and identified four strategic groups - caretakers, marketeers, reorganizers and innovators.

- Dangayach and Deshmuk [18] identified four strategic groups of Indian automobile manufacturers based on the competitive priorities and improvement activities. They named these groups as reactive enterprises, neutral enterprises, active enterprises and proactive enterprises.

Hayes and Wheelwright [7] pointed out that there are different stages in implementing manufacturing strategy and developed "Four-stage model" to evaluate the competitive role and contribution of manufacturing function of any type of company. Stage I organizations react blindly to the demands placed on them and manufacturing function is considered as a necessary evil. In these organizations, strategic role of manufacturing is to minimize the negative impact of the manufacturing function. Stage II organizations are in par with their competitors and follow the industry best practices. In the stages III and IV companies, manufacturing strategy is directly linked with the business strategy. In stage IV organizations manufacturing function provides source competitive advantage through its capabilities and drives the business strategy whereas manufacturing strategy of stage III organizations is developed to support business strategy. Stage IV organizations are proactive and they follow the world class practices. Based on the literature, Mills et al. [19] have reported that the most common target in the research studies has been stage III. But they pointed out that growing interest in the learningorganization, core competences and capabilities compctition may provoke more interest in stage IV.

Performance improvement programmes are another area which has gained the attention of manufacturing strategy researchers. Ferdows and De Meyer [20] identified set of improvement activities related to performance objectives. Miller and Roth [10] indicated 10 improvement programmes in their study in manufacturing strategy. Dangyach and Deshmuk [18] classified 27 improvement activities into three categories: advanced manufacturing technologies, integrated information systems and advanced management systems. Similar improvement activities can be found in the literature [21,22].

\section{Research Methodology}

Since this research is exploratory in nature, the survey methodology is used in this study and focus of the study is cross-sectional. The objective is to understand the present strategy and improvement activities through the survey.

\subsection{Sample selection}

The companies selected for data collection are solely engaged in manufacturing of furniture for local and foreign markets as well as interior decorators supplying custom made furniture. The target firms were selected from the following sources: Directory of ICTAD and Sri Lanka Telecom Business Directory. In these directories, there is large number of small players whose individual contribution is very less for the furniture industry. In order to limit the study to the key players, only the companies which exceed a turnover more than 2.5 million rupees per month were included. Then final population consists of 60 key players of Sri Lankan furniture industry. A randomsample of 40 companies out of these $60 \mathrm{key}$ players was selected to send the questionnaire.

\subsection{Design of questionnaire and data collection}

Astructured questionnaire was developed on five-point Likert scale for data collection. Thequestionnaire contained three sections. Section 1 contained questions to study the competitive priorities of the companies. Eleven competitive priorities were identified based on the literature $[6,8,9,10]$ : low price, conformance quality, product performance, delivery speed, dependable delivery product customization, broad distribution, broad line, after sales service, design flexibility, volume flexibility. Respondent were asked to rate the importance attributed to each of these competitive priorities. These responses were used to identify the different strategic groups in the Sri Lankan furniture industry.

Questions in section 2 were designed to obtain information on the activities of improvements. Based on the literature $[9,18,23,24] 22$ activities relevant to Sri Lankan furniture manufacturers were identified. These activities were classified into three categories: advanced 
manufacturing technologies (AMT), integrated information system (IIS), and advanced management systems (AMS). Table 1 shows the activities of improvement included in the study. Respondents were asked to indicate degree of implementation of these activities in their companies on five point Likert scale (1 no implementation, 5 - high degree of implementation)

Section 3 of questionnaire devoted to identify the manufacturing strategy stage of the organizations based on Hayes and Wheelwright [7] model. Phrases used in the original text of Hayes and Wheelwright [8] and questionnaire developed by Barnes and Rowbotham [25] were used in developing the questionnaire. Language of questions was carefully screened so that questions would be understood in organizations of all kind. Twenty questions were included in the questionnaire. Each question was designed to test particular stage of the Hayes and Wheelwright model. The questions reflect the characteristics given in Table 4 in the section 4 . Respondents were asked to indicate their degree of agreement for the attributes present in their companies on five point Likert scale (1 strongly disagree, 5 - strongly agree). After refining through a pilot study, the questionnaire was sent to manufacturing managers of forty manufacturing firms. Total of 32 filled questionnaires were received for the analysis which resulted in a response rate of $80 \%$.

Table 1: Activities of Improvement

\begin{tabular}{|c|c|c|}
\hline \multirow[b]{2}{*}{$\begin{array}{l}\text { Type } \\
\text { Advanced } \\
\text { manufacturing } \\
\text { technologies } \\
\text { (AMT) }\end{array}$} & Abbreviation & Description \\
\hline & $\begin{array}{l}\text { HTM } \\
\text { AMHS } \\
\text { BC } \\
\text { AS/RS }\end{array}$ & $\begin{array}{l}\text { Computer-aided design: Computer supported design and } \\
\text { drafting } \\
\text { High tech machines: CNC or machines with advanced control } \\
\text { system } \\
\text { Automated material handling system } \\
\text { Bar coding identification system } \\
\text { Automated storage \& retrieval system: mechanized stock } \\
\text { management system }\end{array}$ \\
\hline $\begin{array}{l}\text { Integrated } \\
\text { information } \\
\text { systems } \\
\text { (IIS) }\end{array}$ & MRPII & $\begin{array}{l}\text { Material Requirement Planning: computer assisted material } \\
\text { requirement planning } \\
\text { Manufacturing resource planning: computer based system for } \\
\text { planning and allocation of work among employees and machines } \\
\text { Enterprise resource planning: integrated information system of } \\
\text { all functions }\end{array}$ \\
\hline $\begin{array}{l}\text { Advanced } \\
\text { management } \\
\text { systems } \\
\text { (AMS) }\end{array}$ & $\begin{array}{l}\mathrm{RC} \\
\mathrm{BPR} \\
\mathrm{SPC}\end{array}$ & $\begin{array}{l}\text { Customer relations: maintain relationship with customer } \\
\text { Supplier relations: maintain relationship with supplier to } \\
\text { improve supply performance } \\
\text { Total quality management: approach to improve competitiveness } \\
\text { of an organization through continuous improvement and } \\
\text { participation of all employees } \\
\text { Recycling: reusing waste material } \\
\text { Business process reengineering: improvements through } \\
\text { fundamental rethinking and radical redesign of business process } \\
\text { Statistical process control: use of statistical methods to control } \\
\text { quality } \\
\text { Just-in-time: produce and deliver goods just-in-time } \\
\text { Benchmarking: comparing company's performance against } \\
\text { Workforce involvement: participation of workers in } \\
\text { improvement activities } \\
\text { Employee empowerment: hand over responsibility and decision } \\
\text { making lower level employees } \\
\text { Management training } \\
\text { Labour/management relationships: activities for improving } \\
\text { collaboration between managers and workers } \\
\text { Zero defects programs: reduce rates } \\
\text { Manufacturing lead time reduction }\end{array}$ \\
\hline
\end{tabular}




\section{Observation and Results}

The discussion of the results is divided into three sections. The first section classifies respondent companies into strategic groups based on the compctitive priorities. Importance of improvement activities of each group is identified in the section 2 . The section 3 is devoted to study stages of manufacturing strategy according to Hayes and Wheelwright's model.

\subsection{Strategic groups based on competitive priorities}

Cluster analysis is used to identify the strategic groups of respondent companies based on the competitive priorities. In categorizing the strategic groups this study used eleven competitive priorities. Respondents had indicated degree of importance of these competitive priorities on a five point Likert scale. SPSS quick cluster procedure, K-mean algorithm for non-hierarchical clustering is used to form different strategic groups. In nonhierarchical cluster analysis, number of clusters is known, a priori. To determine the final number of clusters, managerial interpretability of clusters was sought on the defining variable using ANOVA and the Scheffe pair wise comparison tests of mean differences [26]. The three cluster models best satisfied these criteria. Three resultant manufacturing strategic groups are described in Table 2 in terms of their mean scores and their relative ranking in the set of 11 competitive priorities

\section{Cluster 1}

Majority of the respondents falls into cluster 1. This group is similar to the "caretakers" identified by Miller and Roth [9]. These manufacturers rank low price as their first emphasis, while conformance quality and product performance come to $2^{\text {nd }}$ and $3^{\text {rd }}$ places respectively. However, price is not significantly different in importance among the groups. According to the results in Table 2, the companies in cluster 1 give more importance to price and product related competitive priorities such as conformance and performance while given less market related factors such as advertising and broad distribution. It can be seen that importance given to most of the competitive priorities (including top priorities) by cluster 1 is low compare to the degree of importance given by the other two clusters. However their low relative emphasis on the competitive priorities shows that these companies seek the minimum standards for competition and try to just survive in the market place. Less emphasis given for broader product lines and product customization indicated these companies try to offer standard narrow product line and hence to achieve cost efficiency.

\section{Cluster 2}

The competitive priorities of this cluster indicate that this cluster can be named as the "marketeers" defined by Miller and Roth [9]. The companies in cluster 2 differ themselves from other groups on several key market oriented competitive capabilities. They seek to obtain broad line and broad distribution as their $1^{\text {st }}$ and $3^{\text {rd }}$ ranks, while they are significantly conscious about the low price and volume flexibility which are both ranked in $2 \mathrm{nd}$ places on the priority list. Relative importance given for many of the competitive priorities by cluster 2 is higher than that by cluster 1 . This implies that this cluster is keen to be competitive in the market place. The results shows that variety needs of the customers are mainly satisfied through broader product lines and product customization is given less priority.

\section{Cluster 3}

The most important competitive priority of this cluster is conformance quality. Both product performance and delivery speed rank to the $2^{\text {nd }}$ place in the importance of competitive priorities. Importance given to price is comparatively low and it ranks to the $8^{\text {th }}$ place. These results show that the companies in this cluster follow more product oriented approach in competing in the market place. Compare to other two clusters, this cluster provides much emphasis on delivery speed and after-sales services. Product customization and design flexibility are given less priority and both rank $6^{\text {th }}$ place. These two are key competitive priorities for the innovators. Even though the clusters 1 and 2 match with taxonomy of Miller and Roth [9], the cluster 3 does not match with this taxonomy where they named $3^{\text {rd }}$ cluster as the "innovators". The key priorities in this cluster are mainly towards product performance and conformance and hence this cluster is in line 
with the manufacturing group identified by De Meyer et al. [13] where they named the manufacturing group with these key competitive priorities as "high performance product group". This group tries to differentiate their products through high performance and hence this group is named as "Differentiators" in this study.
Table 2 indicates that industry overall figures rank low price, conformance quality and product performance as the major competitive priorities. Apart from these competitive priorities, industry overall shows low degree of importance for the other priorities. This is a clear sign of the existence of a majority of manufacturers whose main focus being survival in the industry.

Table 2: Strategic Groups based on Competitive Priorities

\begin{tabular}{|c|c|c|c|c|}
\hline \multirow[t]{2}{*}{ Competitive Priorities } & \multicolumn{3}{|c|}{ Cluster } & \multirow{2}{*}{$\begin{array}{l}\text { Industry } \\
\text { Overall } \\
(n=32)\end{array}$} \\
\hline & $\begin{array}{l}\text { Group } 1 \\
(n=18)\end{array}$ & $\begin{array}{l}\text { Group } 2 \\
(n=06)\end{array}$ & $\begin{array}{l}\text { Group } 3 \\
(n=08)\end{array}$ & \\
\hline \multicolumn{5}{|l|}{ Low Price } \\
\hline Mean (Rank) & $3.56(1)$ & $3.67(2)$ & $3.13(8)$ & $3.47(1)$ \\
\hline Standard Error & 0.27 & 0.21 & 0.23 & 0.17 \\
\hline \multicolumn{5}{|l|}{ Conformance Quality } \\
\hline $\begin{array}{l}\text { Mean (Rank) } \\
\text { Standard Error }\end{array}$ & $\begin{array}{l}3.22(2) \\
0.10\end{array}$ & $\begin{array}{l}3.00(6) \\
0.00\end{array}$ & $\begin{array}{l}4.00(1) \\
0.27\end{array}$ & $\begin{array}{l}3.38(2) \\
0.11\end{array}$ \\
\hline \multicolumn{5}{|l|}{ Product Performances } \\
\hline Mean (Rank) & $2.83(3)$ & $3.17(5)$ & $3.88(2)$ & $3.16(3)$ \\
\hline Standard Error & 0.15 & 0.17 & 0.35 & 0.14 \\
\hline \multicolumn{5}{|l|}{ Delivery Speed } \\
\hline Mean (Rank) & $2.17(8)$ & $3.00(6)$ & $3.88(2)$ & $2.75(5)$ \\
\hline Standard Error & 0.15 & 0.26 & 0.35 & 0.18 \\
\hline \multicolumn{5}{|l|}{ Dependable Delivery } \\
\hline Mean (Rank) & $2.28(6)$ & $2.67(10)$ & $3.13(8)$ & $2.56(9)$ \\
\hline Standard Error & 0.14 & 0.33 & 0.35 & 0.14 \\
\hline \multicolumn{5}{|l|}{ Product Customization } \\
\hline Mean (Rank) & $2.61(5)$ & $2.00(11)$ & $3.25(6)$ & $2.66(7)$ \\
\hline Standard Error & 0.23 & 0.00 & 0.31 & 0.17 \\
\hline \multicolumn{5}{|l|}{ Broad Distribution } \\
\hline Mean (Rank) & $1.83(10)$ & $3.50(4)$ & $2.5(11)$ & $2.31(11)$ \\
\hline Standard Error & 0.09 & 0.43 & 0.27 & 0.16 \\
\hline \multicolumn{5}{|l|}{ Broad line } \\
\hline Mean (Rank) & $2.22(7)$ & $4.00(1)$ & $2.75(10)$ & $2.69(6)$ \\
\hline Standard Error & 0.13 & 0.26 & 0.25 & 0.16 \\
\hline \multicolumn{5}{|l|}{ After Sales Service } \\
\hline Mean (Rank) & $2.72(4)$ & $2.17(9)$ & $3.63(4)$ & $2.84(4)$ \\
\hline Standard Error & 0.11 & 0.17 & 0.32 & 0.14 \\
\hline \multicolumn{5}{|l|}{ Design Flexibility } \\
\hline Mean (Rank) & $2.00(9)$ & $3.00(10)$ & $3.25(6)$ & $2.50(10)$ \\
\hline Standard Error & 0.00 & 0.45 & 0.16 & 0.14 \\
\hline \multicolumn{5}{|l|}{ Volume Flexibility } \\
\hline Mean (Rank) & $2.00(9)$ & $3.67(2)$ & $3.38(5)$ & $2.66(7)$ \\
\hline Standard Error & 0.00 & 0.21 & 0.18 & 0.15 \\
\hline
\end{tabular}




\subsection{Activities of Improvement}

Degree of implementation of 22 improvement activities in sample companies was obtained through the questionnaire survey. Respondents have indicated degree of implementation of these activities in their companies on five point Likert scale (1 - no implementation, 5 high degree of implementation). Table 3 shows mean and standard error of improvement activities for each cluster.

There is no much significant difference in activities of improvement for different clusters. Effort for using CAD is reasonably high in all the clusters compare to other types of advanced manufacturing technologies. Apart from CAD, the companies in clusters 2 and 3 have given the emphasis in using high tech machines in their manufacturing process, but industry overall for high tech machines is at a lower level. However there is no significant investment for the other advanced manufacturing technologies. It is noticeable that integrated information system implementation is at fairly low level in the Sri Lankan furniture industry. Customer relationship maintenance ranks as the second important activity of improvement and all the groups have given emphasis to improve customer relationship. This implies that the companies in the furniture industry have given much importance due to the huge competition in the industry. In the furniture companies in the clusters 2 and 3 , there are some efforts for employee related improvements such as workforce involvement, employee empowerment and labour/ management relationship.

Table 3: Degree of Implementation of Improvement Activities

\begin{tabular}{lllllllll}
\hline $\begin{array}{l}\text { Activities } \\
\text { Improve- }\end{array}$ of & \multicolumn{2}{c}{ Cluster $\mathbf{1}$} & \multicolumn{2}{c}{ Cluster 2 } & \multicolumn{2}{c}{ Cluster 3 } & \multicolumn{2}{c}{ Industry Overall } \\
\cline { 2 - 9 } & $\begin{array}{l}\text { Mean } \\
\text { (rank) }\end{array}$ & $\begin{array}{l}\text { Std. } \\
\text { Error }\end{array}$ & $\begin{array}{l}\text { Mean } \\
\text { (rank) }\end{array}$ & $\begin{array}{l}\text { Std. } \\
\text { Error }\end{array}$ & $\begin{array}{l}\text { Mean } \\
\text { (rank) }\end{array}$ & $\begin{array}{l}\text { Std. } \\
\text { Error }\end{array}$ & $\begin{array}{l}\text { Mean } \\
\text { (rank) }\end{array}$ & $\begin{array}{l}\text { Std. } \\
\text { Error }\end{array}$ \\
\hline AMT & & & & & & & & \\
CAD & $2.67(2)$ & 0.20 & $3.33(1)$ & 0.42 & $3.38(1)$ & 0.33 & $2.97(1)$ & 0.29 \\
HTM & 1.39 & 0.20 & $2.50(3)$ & 0.67 & $2.88(3)$ & 0.35 & 1.97 & 0.37 \\
AMHS & 1.22 & 0.13 & 1.67 & 0.49 & 1.88 & 0.23 & 1.47 & 0.26 \\
BC & 1.00 & 0.00 & 1.50 & 0.50 & 1.25 & 0.16 & 1.16 & 0.23 \\
AS/RS & 1.11 & 0.08 & 1.50 & 0.50 & 1.50 & 0.19 & 1.28 & 0.24 \\
IIS & & & & & & & & \\
MRP & 1.72 & 0.14 & 2.00 & 0.52 & 2.75 & 0.25 & 2.03 & 0.28 \\
MRPII & 1.44 & 0.13 & 1.66 & 0.41 & 2.13 & 0.30 & 1.65 & 0.25 \\
ERP & 1.39 & 0.12 & 2.00 & 0.52 & 2.38 & 0.18 & 1.75 & 0.26 \\
AMS & & & & & & & & \\
CR & $2.83(1)$ & 0.09 & $2.50(3)$ & 0.22 & $3.38(1)$ & 0.26 & $2.91(2)$ & 0.18 \\
SR & 1.78 & 0.13 & 2.33 & 0.21 & 2.25 & 0.16 & 2.00 & 0.16 \\
TQM & 1.67 & 0.16 & 2.33 & 0.42 & $2.88(3)$ & 0.23 & 2.10 & 0.25 \\
RC & 1.00 & 0.00 & 1.00 & 0.00 & 1.13 & 0.12 & 1.03 & 0.06 \\
BPR & 1.00 & 0.00 & 1.33 & 0.33 & 1.25 & 0.16 & 1.12 & 0.17 \\
SPC & 1.17 & 0.09 & 1.50 & 0.34 & 2.13 & 0.30 & 1.47 & 0.22 \\
JIT & 1.22 & 0.10 & 2.00 & 0.26 & 2.13 & 0.30 & 1.59 & 0.20 \\
BM & $2.28(3)$ & 0.14 & 1.83 & 0.31 & 2.25 & 0.16 & 2.19 & 0.19 \\
WI & 1.94 & 0.19 & $2.50(3)$ & 0.43 & 2.25 & 0.16 & 2.12 & 0.25 \\
EE & 1.89 & 0.18 & $2.67(2)$ & 0.33 & 2.63 & 0.18 & $2.22(3)$ & 0.22 \\
MT & 1.33 & 0.12 & 1.83 & 0.31 & 2.50 & 0.33 & 1.72 & 0.23 \\
LMR & 1.61 & 0.16 & 2.17 & 0.31 & 2.38 & 0.26 & 1.91 & 0.22 \\
ZD & 1.17 & 0.09 & 1.50 & 0.34 & 1.63 & 0.37 & 1.35 & 0.25 \\
MLR & 1.44 & 0.12 & 1.83 & 0.31 & 2.63 & 0.33 & 1.81 & 0.23 \\
\hline * & & & & & & & & \\
\hline
\end{tabular}

* Only first three ranks are shown. 
In terms of advanced management system related programmes, the companies in cluster 1 give very little or no emphasis for improvement activities except benchmarking. The cluster 1 is the weakest group in the furniture industry and probably they are trying to benchmark the best practice companies in the industry. In the cluster 3 practices of TQM and statistical process control are at a higher level compared, to the other two groups. This demonstrates effort made by cluster 3 for conformance quality, which is their number one competitive priority. It is further noted that in the companies of cluster 3, emphasis given for reducing manufacturing lead time is comparatively high and it shows the dedication for meeting their second important competitive priority "delivery speed". The improvement activities such as business process reengineering, recycling and zero defects have not yet grabbed the attention of furniture industry.

Table 4: Stages of Manufacturing Strategy

\begin{tabular}{|c|c|c|c|c|c|}
\hline Stage & Description & Attributes & Mean & $\begin{array}{l}\text { Standard } \\
\text { Error }\end{array}$ & $\begin{array}{l}\text { Stage Mean } \\
\text { (Error) }\end{array}$ \\
\hline \multirow[t]{5}{*}{ I } & Internally & Use new technology only for survival & 2.13 & 0.13 & \multirow{5}{*}{$\begin{array}{r}2.34 \\
(0.12)\end{array}$} \\
\hline & \multirow[t]{4}{*}{ Neutral } & $\begin{array}{l}\text { Manufacturing is not linked to business } \\
\text { strategy }\end{array}$ & 2.44 & 0.12 & \\
\hline & & $\begin{array}{l}\text { Top management involvement only } \\
\text { when performance is low. }\end{array}$ & 2.53 & 0.11 & \\
\hline & & $\begin{array}{l}\text { Short term operations aspects are } \\
\text { expected }\end{array}$ & 2.47 & 0.13 & \\
\hline & & Customer needs not widely grasped & 2.13 & 0.10 & \\
\hline \multirow[t]{5}{*}{ II } & \multirow[t]{5}{*}{$\begin{array}{l}\text { Externally } \\
\text { Neutral }\end{array}$} & $\begin{array}{l}\text { Aims to achieve parity with the } \\
\text { compctitors }\end{array}$ & 3.25 & 0.11 & \multirow{5}{*}{$\begin{array}{l}3.33 \\
(0.13)\end{array}$} \\
\hline & & Identification of basic customer needs & 3.78 & 0.11 & \\
\hline & & $\begin{array}{l}\text { Use new technology only for cost savings } \\
\text { Set procedures are maintained to achieve }\end{array}$ & $\begin{array}{l}3.25 \\
3.25\end{array}$ & 0.15 & \\
\hline & & efficiency & 0.0 & 0.17 & \\
\hline & & $\begin{array}{l}\text { Manufacturing is not involved in } \\
\text { strategic issues }\end{array}$ & 3.13 & 0.15 & \\
\hline \multirow[t]{5}{*}{ III } & \multirow[t]{5}{*}{$\begin{array}{l}\text { Internally } \\
\text { Supportive }\end{array}$} & $\begin{array}{l}\text { Quality exceeds the expectations of } \\
\text { customers }\end{array}$ & 3.34 & 0.09 & \multirow{5}{*}{$\begin{array}{c}3.23 \\
(0.13)\end{array}$} \\
\hline & & $\begin{array}{l}\text { Use new technology when it promises } \\
\text { product/process enhancements }\end{array}$ & 3.19 & 0.16 & \\
\hline & & $\begin{array}{l}\text { Manufacturing strategy is aligned with } \\
\text { business strategy }\end{array}$ & 3.13 & 0.14 & \\
\hline & & Centralized decision making adopted & 3.06 & 0.13 & \\
\hline & & $\begin{array}{l}\text { Superior position is important than } \\
\text { competition }\end{array}$ & 3.44 & 0.12 & \\
\hline \multirow[t]{5}{*}{ IV } & \multirow[t]{5}{*}{$\begin{array}{l}\text { Externally } \\
\text { Supportive }\end{array}$} & $\begin{array}{l}\text { Long range programmes are pursued in } \\
\text { order to acquire manufacturing } \\
\text { capabilities in advance }\end{array}$ & 3.13 & 0.14 & \multirow{5}{*}{$\begin{array}{c}303 \\
(0.132)\end{array}$} \\
\hline & & $\begin{array}{l}\text { Efforts are made to anticipate the } \\
\text { potential of ncw manufacturing } \\
\text { technologies, policies as unique features }\end{array}$ & 2.83 & 0.09 & \\
\hline & & $\begin{array}{l}\text { In-house process improvements in } \\
\text { anticipation new attributes in the future }\end{array}$ & 2.92 & 0.19 & \\
\hline & & $\begin{array}{l}\text { View customers as opportunists in } \\
\text { creating new ideas }\end{array}$ & 3.13 & 0.13 & \\
\hline & & $\begin{array}{l}\text { Manufacturing capabilities provide } \\
\text { credible support to develop business } \\
\text { strategy }\end{array}$ & 3.16 & 0.12 & \\
\hline
\end{tabular}




\subsection{Stage of Manufacturing Strategy}

Attributes of various manufacturing strategy stages I - IV, given by Hayes and Wheelwright [8] and degree of agreement of the respondents for these attributes present in their companies are given in Table 4 (1 strongly disagree, 5 - strongly agrce). It is observed from the Table 4 that the mean is highest for stage II, which depicts that majority of the companies of Sri Lankan furniture industry follow the industry practices and in par with the competitors. However, mean rating for the stage III is not much different from that of stage II. This is indicates that there are reasonable number of companies which try to link manufacturing strategy with their business strategy.

\section{Conclusion}

This research identifies three strategic groups of Sri Lankan furniture manufacturers based on 10 competitive priorities. The taxonomy developed in this study has much in common with that of Miller \& Roth [10]. Their "caretakers" and "marketeers" match with the clusters 1 and 2 respectively but "innovators" does not match with cluster 3 . In the formation of strategic groups it is not possible to identify a group with innovative characteristics. This shows the lack of innovativeness of the Sri Lankan furniture companies. The majority of the companies consider the low price as the dominant competitive priority. Many competitive priorities other than price, product performance and conformance are given lower importance even below the moderate level.

The cluster 1, "caretakers" does not give much importance to improvement activities. The clusters 2 and 3 (marketeers and differentiators) pay much attention for the improvement activities compared to the cluster 1. In both groups $C A D$ and high-tech machines have become the priorities in implementing advanced manufacturing technologies. Apart from CAD and high-tech machines, implementation of other advanced manufacturing technologies is at a very low level. Use of integrated information systems is at a very low level in the furniture industry in spite of much popularity of ERP in Sri Lankan manufacturing sector. Lack of interest on advanced manufacturing technologies and integrated information system may be due to the fact that still the furniture industry is considered as a low-tech traditional industry in spite of immense competition. Advanced management systems have not gained much attention for improving performance. Except customer relationship maintenance and employee empowerment, other improvement activities show very low importance in the furniture industry.

In implementing manufacturing strategy it reveals that many organizations fall to stage II of Hayes \& Wheelwright's model. This indicates that majority of organizations attempt to be in par with the industry practices. However, many organizations have certain characteristics of stage III of Iayes and Wheelwright model. This situation indicates that companies in the Sri Lankan furniture industry should work hard to follow strategies of stage IV in order to achieve leader status and to face global competition.

In formulating manufacturing strategy Sri Lankan furniture manufacturers should follow more proactive approach in order to face global competition. They have to go beyond preliminary competitive priorities such as price and conformance and should come up with more market oriented competitive priorities. Manufacturing managers and engineers should plan their improvement activities to meet these priorities through manufacturing and related operations. The furniture manufacturers should understand the importance of advanced manufacturing technologies for improving the performance and should consider the possibilities in implementing technologies beyond $\mathrm{CAD}$. In searching the avenues for enhancing the competitiveness, the companies in the Sri Lankan furniture industry should not overlook the role of integrated information systems and management oriented improvement programmes.

\section{References}

1. http://ec.europa.eu/enterprise/furniture, Visited, 20th July, 2008.

2. Kaplinsky, R., Morris, M. \& Readman, J. C., “The Globalization of Product Markets and Immiserizing Growth: Lessons from the South African Furniture Industry", World Development, Vol. 30, No.7, 2002, pp.1159-1177.

3. http://www.furnituremanufacturers.net, Visited, 20th July, 2008.

4. http://www.manufacturingnews.com, Visited, 20th July, 2008. 
5. Dassanayaka, S. W. S. B., "A Brief Note on Small and Medium Scale Enterprises in Sri Lanka", Paradigm, Vol. 10, No.1, 2006, pp. 69-76.

6. Skinner, W., "Manufacturing: Missing Link in Corporate Strategy", Harvard Business Review, May - June, 1969, pp. 136-145.

7. Hayes, D. R. \& Wheelwright, S. C., Restoring our Competitive Edge, John Wiley and Sons, New York, 1984.

8. Hill, T. J., Manufacturing Stralegy: Text and Cases, University of Bath, lrwin, 1989.

9. Miller, J. G. \& Roth, A. V., "A Taxonomy of Manufacturing Strategies", Managenent Science, Vol. 40, No. 3, 1994, pp. 285-304.

10. Giffi C., Roth, A. V. \& Seal, G., Cumpeting in World Class Manufacturing: America's 21st Century Challenge, Business One Irwin, Homewood, IL, 1990.

11. Noori, H. \& Radford, R., (1993). "Modeling of a World Class Operations", Industrial Management, 1993, pp. 23-29.

12. Wheelwright, S. C., Japan - Where Operations Are Truly Strategic, Harvard Business Review, May-June, 1981.

13. De Meyer, A., Nakane, J., Miller, J. G. \& Ferdows, K. (1989). Flexibility: The Next Competitive Battle, Strategic Managentent Journal, Vol. 10, No.2, pp. 135-44.

14. Slack, N., Manufacturing Advantage: Achieving Competitive Manufacturing Operations, Mercury, London, 1991.

15. Schonberger, R. J., Building a Chain of Customers, Hutchinson Business Books, London, 1990.

16. Stobaugh, R. \& Telesio, P. "Match Manufacturing Policies and Product Strategy", Hanard Business Review, March-April, 1983.

17. Sweeney, M. T. \& Szwejczewski, M., "Manufacturing Strategy and Performance, A Study of the UK Engineering Industry", International Journal of Operations \& Production Management, Vol. 16, No. 5, 1996, pp. 25-40.

18. Dangayach, G. S. \& Deshmuk, S. G., "Practice of Manufacturing Strategy: Evidence from Select Indian Automobile Companies", Intemational joumal of Production Research, Vol. 39, No.11, 2001, pp. 2353-2393
19. Mills, J., Platts, K. \& Gregory, M., "A Framework for the Design of Manufacturing Strategy Processes: A Contingency Approach", Intenational Joumal of Operations \& Production Management, Vol. 15, No. 4, 1995, pp. 17-49.

20. Ferdows K. \& De Meyer A., "Lasting Improvements in Manufacturing Performance: In Search of a New Theory", Journal of Operations Management, Vol. 9, No. 2, 1990, pp 170-184.

21. Mechling G. W., Pearce J. W. \& Busbin J.W. "Exploiting AMT in Small Manufacturing Firms for Global Competitiveness", Intemational Journal of Operations and Production Management, Vol. 15, No. 2, 1995, pp. 61-75.

22. Udo, G. J. \& Ehie, I. C., "AMTs: Determinants of Implementation Success", International Journal of Operations and Production Management, Vol. 16, No. 12, 1996, pp.6-26.

23. Clark, K. B. "Competing through Manufacturing and the New Manufacturing Paradigm: Is Manufacturing Strategy Passe?" Production and Operations Managentent, 5, 1996, pp. 42-58.

24. Bolden, R., Wareson, P., Warr, P. Clegg, C. \& Walt, T.,"A New Taxonomy of Modern Manufacturing Practices", International Journal of Operations and Production Management, Vol. 17, 1997, pp.1112-1130.

25. Barnes, D. \& Rowbotham, F." "Developing a Questionnaire for the Four-Stage Model of Operations Strategy", Production Plaming and Control, Vol. 14, No. 7, 2003, pp. 613-622.

26. Harrigan, K. R., "An Application of Clustering for Strategic Group Analysis", Strategic Management Journal, Vol. 10, 1985, pp. 55-73. 